\title{
Modeling carbon dynamics in two adjacent spruce forests with different soil conditions in Russia
}

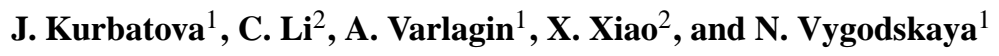 \\ ${ }^{1}$ A.N. Severtsov Institute of Ecology and Evolution, Russian Academy of Sciences, Moscow, Russia \\ ${ }^{2}$ Institute for the Study of Earth, Oceans, and Space, University of New Hampshire, Durham, NH 03824, USA
}

Received: 5 December 2007 - Published in Biogeosciences Discuss.: 24 January 2008

Revised: 14 May 2008 - Accepted: 4 June 2008 - Published: 1 July 2008

\begin{abstract}
Net ecosystem carbon exchange (NEE) was measured with eddy covariance method for two adjacent forests located at the southern boundary of European taiga in Russia in 1999-2004. The two spruce forests shared similar vegetation composition but differed in soil conditions. The wet spruce forest (WSF) possessed a thick peat layer $(60 \mathrm{~cm})$ with a high water table seasonally close to or above the soil surface. The dry spruce forest (DSF) had a relatively thin organic layer $(5 \mathrm{~cm})$ with a deep water table $(>60 \mathrm{~cm})$. The measured multi-year average NEE fluxes (2000 and $1440 \mathrm{~kg} \mathrm{Cha}^{-1} \mathrm{yr}^{-1}$ for WSF and DSF, respectively) indicated that WSF was a source while DSF a sink of atmospheric carbon dioxide $\left(\mathrm{CO}_{2}\right)$ during the experimental years. A process-based model, Forest-DNDC, was employed in the study to interpret the observations. The modeled multi-year average NEE fluxes were 1800 and $-2200 \mathrm{~kg} \mathrm{Cha}^{-1} \mathrm{yr}^{-1}$ for WSF and DSF, respectively, which were comparable with observations. The modeled data also showed high soil heterotrophic respiration rates at WSF that suggested that the water table fluctuation at WSF could have played a key role in determining the negative carbon balance in the wetland ecosystem. A sensitivity test was conducted by running Forest-DNDC with varied water table scenarios for WSF. The results indicated that the NEE fluxes from WSF were highly sensitive to the water table depth. When the water table was high, the WSF ecosystem maintained as a sink of atmospheric $\mathrm{CO}_{2}$; while along with the drop of the water table the length of the flooded period reduced and more organic matter in the soil profile suffered from rapid decomposition that gradually converted the ecosystem into a source of atmospheric $\mathrm{CO}_{2}$. The general effect of water table variation on wetland carbon balance observed from this model-
\end{abstract}

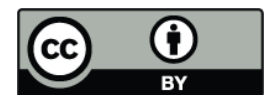

Correspondence to: $\mathrm{C} . \mathrm{Li}$ (changsheng.li@unh.edu) ing study could be applicable for a wide range of wetland ecosystems that have accumulated soil organic carbon while face hydrological changes under certain climatic or land-use change scenarios.

\section{Introduction}

Boreal forests contain about $50 \%$ of the total carbon stored in vegetation and soils in the world (Dixon et al., 1994). The majority of boreal forests are distributed in Russia (600 million ha), Europe (300 million ha) and North America (500 million ha) (Schulze et al., 1999). Boreal forests play an important role in the global cycles of carbon (C), water and nutrients as well as the climate system. A number of global $\mathrm{C}$ balance studies have suggested that there is very likely a large $\mathrm{C}$ sink in the northern Hemisphere, but its spatial patterns and temporal dynamics remain uncertain (Schimel et al., 2001; Fan et al., 1998; Myneni et al., 2001). Multiple biological and abiotic factors, including climate variation, land use change, and frequent natural disturbance (e.g., fire, insect outbreak), could significantly affect the carbon dioxide $\left(\mathrm{CO}_{2}\right)$ fluxes and $\mathrm{C}$ storage in the boreal forest regions (Shvidenko and Nilsson, 2002; Jarvis and Linder, 2000; Kobak et al., 1996). The existing estimates of net primary production for boreal forests vary widely (Melillo et al., 1993; Schulze et al., 1999; Jarvis et al., 2001; Jarvis and Linder, 2000).

To better quantify the role of boreal forests in the global carbon cycle, the international research communities recently made great efforts establishing a net work of $\mathrm{CO}_{2}$ eddy flux towers across boreal forests in Northern Eurasia through programs such as AsiaFlux, EuroFlux, and ChinaFlux (Schulze et al., 1999; Hollinger et al., 1998; Roeser et al., 2002; Lloyd et al., 2002; Hamada et al., 2004; Ohta et al., 2001). The eddy flux tower network has produced and

Published by Copernicus Publications on behalf of the European Geosciences Union. 


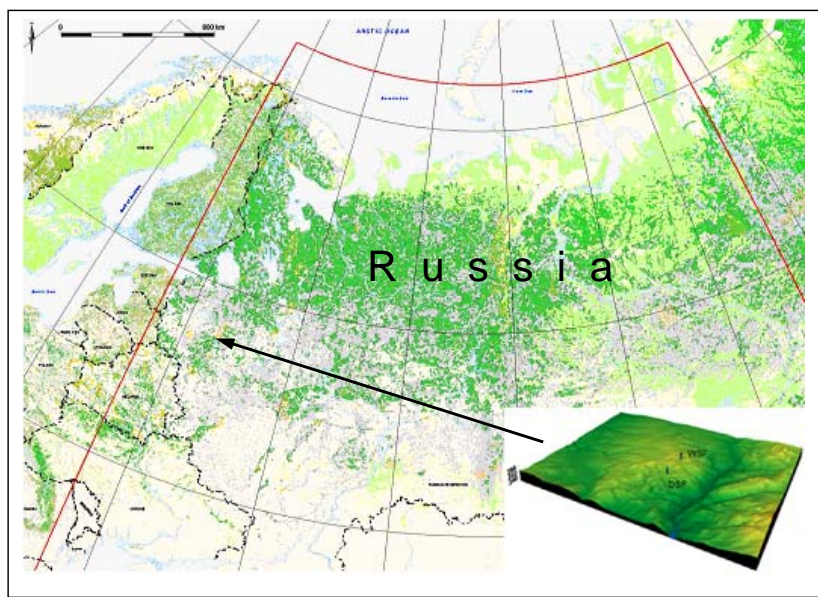

Fig. 1. Location of the studied wetland spruce forest (WSF) and upland spruce forest (DSF) in the Central Forest Biosphere Reserve at Fyodorovskoe in Tver, Russia.

will continuously produce rich data sets of net ecosystem exchange of $\mathrm{CO}_{2}$ (NEE) between forests and the atmosphere at the tower sites. NEE is defined as the difference between gross primary production (GPP) and ecosystem respiration $\left(R_{e}\right)$ consisting of the plant autotrophic respiration and the soil microbial heterotrophic respiration. The analyses with the observed NEE flux data have been conducted and demonstrated interesting but complex patterns on the seasonal dynamics and inter-annual variations of the NEE fluxes (Falge et al., 2002).

Carbon dynamics represented by the observed NEE fluxes for the forest ecosystems is regulated by a series of primary drivers including climate, soil, hydrology, vegetation, and management practices. Any single change in the primary drivers could simultaneously alter several of the forest environmental factors such as radiation, temperature, soil moisture, soil redox potential, and nutrient substrates dynamics; and the altered environmental factors could collectively and simultaneously affect the plant photosynthesis and/or the ecosystem respiration ( $\mathrm{Li}, 2007)$. Sometimes, the interactions between the changes in primary drivers and the forest responses are so complex that it is hard to reveal the mechanisms that controlling the forest $\mathrm{C}$ dynamics solely relying on the observed NEE fluxes. Process-based models have been developed to meet the gap. During the past decade a number of models were developed by integrating the fundamental processes that govern the forest growth, litter incorporation, and soil organic matter (SOM) turnover. Driven by climate, forest type, soil properties, management practices and other relevant input parameters, the models can simulate forest production as well as $\mathrm{C}$ and $\mathrm{N}$ cycles in the ecosystems. Among the modeling efforts, the Forest-DNDC model developed by $\mathrm{Li}$ and his colleagues ( $\mathrm{Li}$ et al., 2000) has been widely tested for greenhouse gas studies (Butterbach-Bahl et al., 2004; Kiese et al., 2004; Cui et al., 2005; Kesik et al., 2005; Miehle et al., 2006). In this study, we applied ForestDNDC for understanding the NEE fluxes observed at two adjacent forest ecosystems located at the southern boundary of European taiga in Russia. The two forests shared similar composition though differing in soil and hydrological conditions. The multi-year observation data indicated that one of the forests was continuously a sink of atmospheric $\mathrm{CO}_{2}$ while the other a source. By tracking the various $\mathrm{C}$ fluxes in the two forest stands with the modeling tool, we tried explaining why the two forests functioned differently regarding their contributions to atmospheric $\mathrm{C}$.

\section{Description of study sites}

Net ecosystem exchange of carbon (NEE) was measured with eddy covariance technique at two adjacent forested sites in the Central Forest Biosphere Reserve $\left(56^{\circ} 27^{\prime} \mathrm{N}, 32^{\circ} 55^{\prime} \mathrm{E}\right)$ at Fyodorovskoe in Tver, Russia from 1999-2004 (Fig. 1). The reserve was established in 1931 possessing an area of 24447 ha with an elevation of $230-270 \mathrm{~m}$. The forests have been being reserved without any commercial disturbance since the 1960s. The territory of the reserve is far from any industrial or residential areas with little air pollution affecting the forest growth. The two measured sites, the wet and dry spruce forests, are located about $2 \mathrm{~km}$ apart from each other. The sites have similar climatic conditions with average annual temperature $3.9^{\circ} \mathrm{C}$ and precipitation $711 \mathrm{~mm}$ for the 1990s (Milyukova et al., 2002).

The wet spruce forest (WSF) site is an old (150 years) spruce forest with spruce (Picea abies, 86\%) and birch (Betula pubescens, 14\%). The undergrowth is dominated by Vaccinium spp. and Sphaghum spp. Above-ground woody biomass is approximately $53 \mathrm{tC} \mathrm{ha}^{-1}$ (Milyukova et al., 2002). The measurement tower is located on a flat surface with homogenous vegetation cover. The stand has a 60 $\mathrm{cm}$ Sphagnum peat layer with the tree roots throughout the whole profile. The soil $\mathrm{C}$ content in the peat layer is about 197 ton $\mathrm{Cha}^{-1}$ (Vygodskaya et al., 2002). The forest is characterized by poor soil aeration, low $\mathrm{pH}(3.5-3.8)$ and low nitrogen content $\left(0.5-9.9 \mathrm{~kg} \mathrm{ha}^{-1}\right)$. The water table is seasonally close to or above the soil surface. The water table usually reaches the soil surface in spring. The dry spruce forest (DSF) site is an old (80-150 years) spruce forest with Picea abies (53\%), Betula pubescens (5\%), Populus tremula (6\%), Ulmus glabra (6.4\%), Acer platanoides (18\%) and others growing on a well-drained slope. The organic layer is less than $5 \mathrm{~cm}$. The water table is usually at a depth of $1.5 \mathrm{~m}$ (Vygodskaya et al., 2004a;Vygodskaya et al., 2004b). 


\section{Measurement of NEE fluxes}

The eddy covariance system employed at the experimental sites was similar to that used in the Euroflux project (Aubinet et al., 2000). Briefly, a three-axis sonic anemometer with an omni directional head (Solent R3, Gill Instruments, Lymington, UK) was installed in $29 \mathrm{~m}$ and $44 \mathrm{~m}$ heights atop metal tower at WSF and DSF respectively. The instrument provides high frequency measurements $(20 \mathrm{~Hz})$ of the wind speed and the air temperature. For measurements of $\mathrm{CO}_{2}$ and water vapor concentration, air was drawn from an inlet atop of the tower through a 1/4" inner diameter BEV-A-LINE tubing to a closed-path infrared gas analyzer (IRGA; LI-COR 6262, Lincoln, NE USA) located close to the bottom of the tower in an insulated wooden shelter. The suction pump was placed in front of the analyzer gas-inlet to ensure the air to be pushed through the instrument with a flow rate of approximately $6 \mathrm{~L} \mathrm{~min}^{-1}$. A pressure transducer (PTP101B, Vaisala, Helsinki, Finland) in the reference cell provided the necessary information to correct the measurements for variations associated with pressure fluctuations induced by the pump. The analyzer was run in absolute mode with $\mathrm{CO}_{2}$ and waterfree air circulating in the reference cell, using a combination of magnesium perchlorate and soda-lime. Calibration of the instrument was checked regularly once a week using air of known $\mathrm{CO}_{2}$ (pressure bottle) and $\mathrm{H}_{2} \mathrm{O}$ (dew-point generator, LI 610, LI-COR, Lincoln, NE USA) concentrations. Output from the sonic anemometer and infrared gas analyzer were read at $20 \mathrm{~Hz}$ through RS-232 ports and stored into computers for subsequent analysis.

Ambient $\mathrm{CO}_{2}$ concentrations at heights of $0.20,1.0,2.0$, 5.0, 11.0, 15.6, 25.0, $27.6 \mathrm{~m}$ and $0.25,1.0,2.0,5.80$, $22.60,33.40,42.8 \mathrm{~m}$ at the WSF and DSF, respectively, were recorded with a system consisting of a LiCor nondispersive infrared gas analyzer (Li-Cor 6251, LI-COR, Lincoln, NE USA), pump (KNF, Neurberger, Germany), switching manifold, BEV-A-Line tubing and datalogger (Campbell, model CR23X). Air was drawn through the tubes at a rate of $7 \mathrm{~L} \mathrm{~min}^{-1}$, with each height being samples for $2 \mathrm{~min}$, with the reading taken at rate of $1 \mathrm{~Hz}$ over the last $10 \mathrm{~s}$ of sampling at each height and averaged before being stored.

The eddy towers was also equipped with instruments to measure environmental factors which have been used for the procedure of gap filling: incoming photosynthetic photon flux density (model LI-190SA, Lincoln, NE USA), humidity and temperature (model HMP35D, Vaisala, Helsinki, Finland), shortwave downward and upward radiation (CM14, Kipp and Zonen, Delft, Holland). Precipitation was collected on the height of $1 \mathrm{~m}$ above ground and was measured by a tipping bucket rain gauge (model 52202, R. M. Young Company, Traverse City, USA). Soil temperature was measured by platinum resistance thermometers (Geratherm, Geschwenden, Germany) at two profiles at depths of 5, 15, 50 and $100 \mathrm{~cm}$ and then averaged for every depth. All meteorological data were collected every $10 \mathrm{~s}$, and $10 \mathrm{~min}$ averages or sums (precipitation only) were stored in the datalogger (Dl3000, Delta-T, Burwell, UK). For comparison with halfhourly eddy flux data, 30 min averages of the environmental data were subsequently calculated. The data of local weather station for precipitation were used during the period of disturbances of a tipping bucket rain gauge. The water table depth was measured by a ruler at the observation wells once a week.

The methods for gap filling procedure and estimating of average annual NEE have been described in detail by Van der Molen et al. (2007). The methods can be summarized as follows:

Eddy Covariance Data acquires and primary process with the software "Eddymeas" (Kolle and Rebmann, 2007). On the next stage the half-hourly data sets were processed using a standardized methodology described in Papale et al. (2006); Reichstein et al. (2005). The fluxes of $\mathrm{CO}_{2}$ were corrected for within-canopy $\mathrm{CO}_{2}$ storage, filtering for lowturbulence night conditions using a friction velocity threshold criterion, spikes are detected. During the period analyzed (1999-2004) the different quality tests discarded part of the measured NEE data, leading yearly data coverage of 39-47\% for night time and $58-71 \%$ for day time datasets. For gapfilling procedure was performed Marginal Distribution Sampling (MDS) method (Reichstein et al., 2005; Moffat et al., 2007).

Eddy tower measurements were conducted at WSF and DSF for six years from 1999-2004. A complete dataset of daily NEE fluxes measured at the WSF site were achieved for the entire measurement time span. The multi-year average annual NEE flux for the WSF site was of about $2000 \mathrm{~kg} \mathrm{Cha}^{-1}$ per year (standard deviation of annual NEE was $\left.1031 \mathrm{~kg} \mathrm{Cha}^{-1}\right)$. However, the observed data at the DSF site were not as complete as that at the WSF site due to the malfunctions of the instruments at DSF. The continuous measurements at DSF only covered a time periods: 7 October-21 November in 1999; 7 June-5 September in 2000; 18 June-7 July and 27 July-31 December in 2002; 1 January-15 May and 26 August-10 November in 2003; and 31 May-30 June and 28 July-20 September in 2004. Based on the limited measurements, an average annual NEE flux was estimated as $-1440 \mathrm{~kg} \mathrm{C} / \mathrm{ha}$ for $\mathrm{DSF}^{1}$. The observations indicated that the two adjacent forests, WSF and DSF, acted as a source and a sink, respectively, of atmospheric $\mathrm{CO}_{2}^{1}$. Water table depths were measured at WSF and DSF in 2004.

\footnotetext{
${ }^{1}$ van der Molen, M. K., Dolman, A. J., Marchesini, L. B., Ciais, P., Corradi, C., Heimann, M., Kuwada, T., Kononov, A.V., Kurbatova, J., Maximov, T., Moors, E., Nakai, T., Schulze, E., Shibistova, O., Ohta, T., Valentini, R., Varlagin, A., Viovy, N., Vygodskaya, N., Zimov, S.: The carbon balance of the Boreal Eurasia consolidated with eddy covariance observations, Global Change Biol., submitted, 2007.
} 


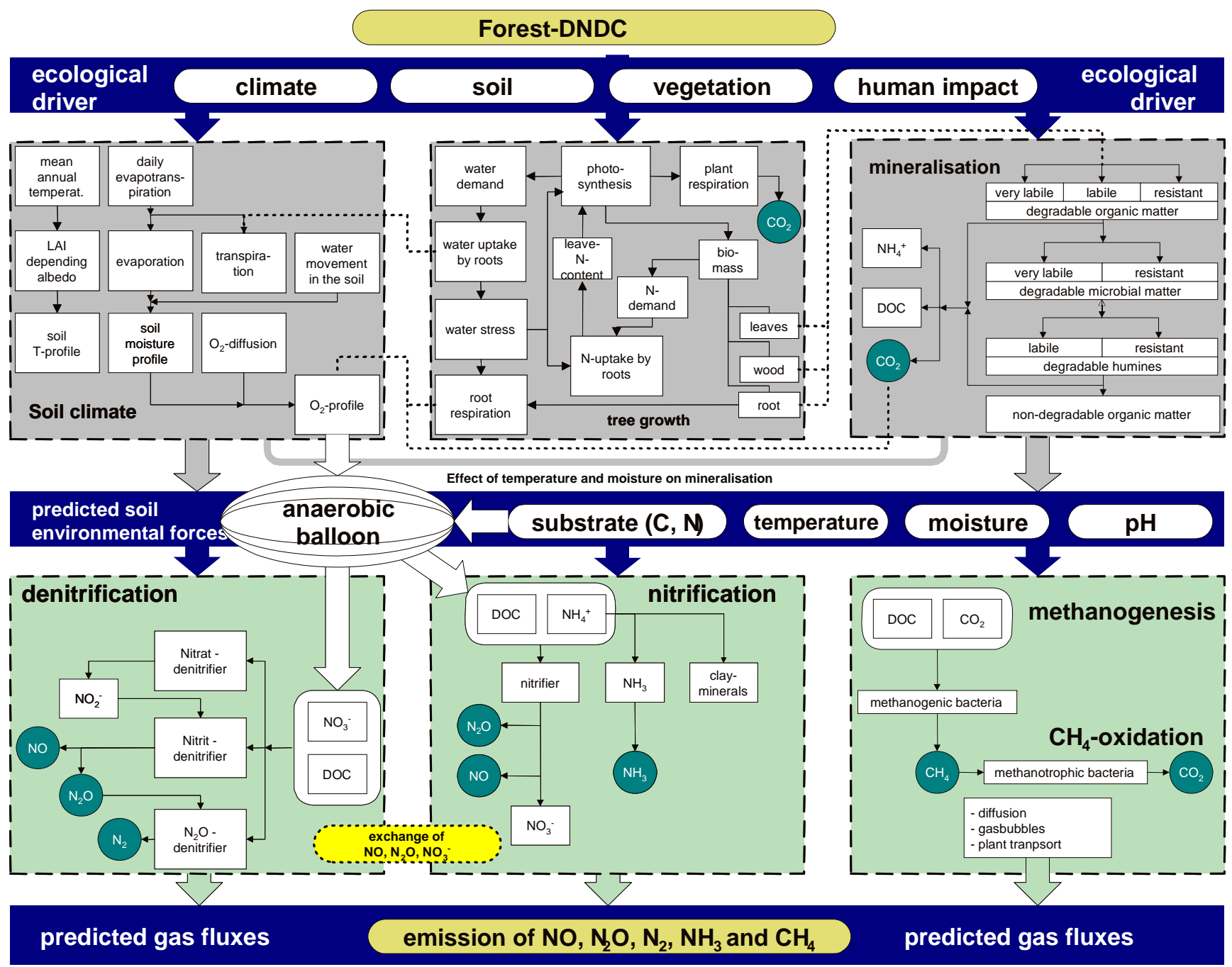

Fig. 2. Structure of the Forest-DNDC model.

\section{Validations of Forest-DNDC}

Forest-DNDC is a generic forest biogeochemical model. The model was developed by integrating two existing models, an upland forest model PnET-N-DNDC ( $\mathrm{Li}$ et al., 2000; Stange et al., 2000) and a wetland forest model WetlandDNDC (Zhang et al., 2002; Li et al., 2004; Cui et al., 2005). Equipped with the upland and wetland features from the parent models, Forest-DNDC is capable of simulating both aerobic and anaerobic processes at landscape scale. ForestDNDC consists of two components. The first component consisting of the soil climate, plant growth and decomposition sub-models converts the primary drivers (e.g., climate, soil properties, vegetation and anthropogenic activity) to soil environmental factors (e.g., temperature, moisture, $\mathrm{pH}$, Eh and substrate concentration gradients); and the second com- ponent consisting of the nitrification, denitrification and fermentation sub-models predicts transformations of $\mathrm{C}$ and $\mathrm{N}$ driven by the soil environmental factors (Fig. 2). The six interacting sub-models form a computable framework to simulate the forest growth and soil biogeochemical processes including SOM turnover and emissions of $\mathrm{CO}_{2}$, nitrous oxide $\left(\mathrm{N}_{2} \mathrm{O}\right)$, nitric oxide $(\mathrm{NO})$, dinitrogen $\left(\mathrm{N}_{2}\right)$ and methane $\left(\mathrm{CH}_{4}\right)$. The modeled NEE flux is the net sum of the simulated photosynthesis (i.e., gross primary production), plant autotrophic respiration and soil microbial heterotrophic respiration. Forest-DNDC possesses a one-dimension hydrological routine to track the vertical movement of water in the soil profile. The soil water flow and moisture are modeled based on precipitation, evapotranspiration and soil texture (Zhang et al., 2002). If the simulated ecosystem is a wetland forest, the model will require daily ground water table 

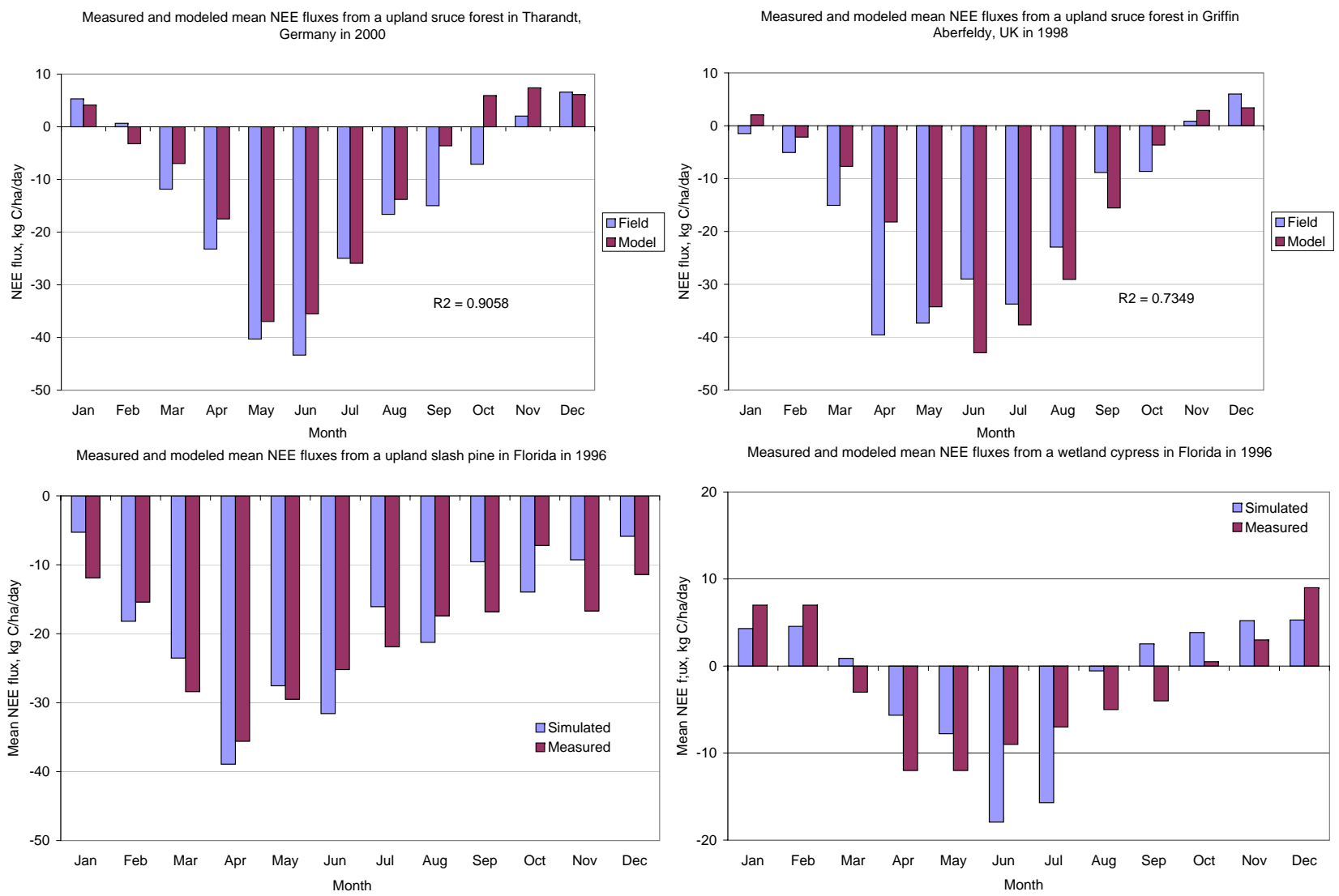

Fig. 3. Comparison between observed and Forest-DNDC modeled NEE fluxes for a upland spruce forest in Tharandt, Germany (a), a upland spruce forest in Griffin-Aberfeldy, the UK (b), a upland slash pine (c) and a wetland cypress (d) in Gainesville in Florida, the US. All the tested forest were sinks of atmospheric $\mathrm{CO}_{2}$ although the wetland cypress at Gainesville sequestered the least $\mathrm{C}$.

depth (WT) as an input parameter to define the saturated and unsaturated zones in the modeled soil profile. The input WT data can be obtained from one of three optional sources including (1) field-observed WT, (2) predicted WT with empirical parameters developed with historical WT data, and (3) predicted WT with spatial distribution hydrological models based on the watershed information (e.g., topography, climate, soil and vegetation). An interface has been built in Forest-DNDC to allow users to select one of the options to define the WT fluctuation.

To test the applicability of Forest-DNDC for upland and wetland forests, we applied the model for four forest ecosystems in Europe and the US. The tested forests included an upland spruce plantation in Tharandt, Germany, an upland spruce forest in Griffin-Aberfeldy, the UK, a upland slash pine in Florida, the US, and a wetland cypress in Florida, the US. The measured NEE flux data were obtained from Christian Bernhofer for the Tharandt site, John Moncrieff for the Griffin-Aberfeldy site, and Clark et al. (1999 and 2004) for the Gainesville sites. The European data were accessible in the CarboeuropeIP database at http://gaia.agraria.unitus.it/ database (Papale et al., 2006 and Moffat et al., 2007). The two European stands were spruce plantations with relatively young ages (20-50 years old). The measured NEE fluxes indicated that the forests were sinks of atmospheric $\mathrm{CO}_{2}$ on an annual basis (Fig. 3a and b). The two American forests were located within a same watershed near Gainesville, Alachua County in north central Florida. The watershed consisted of wetland pond cypress swamps and upland slash pine stands. NEE fluxes were measured with eddy covariance method in the two stands in 1996. The measured NEE data suggested that the cypress wetland had highly contrasting daytime and nighttime carbon flux patterns in comparison with the adjacent upland slash pine stand. On an annual basis, the wetland forest accumulated much less carbon than the upland pine mainly due to the lower photosynthesis rates and higher respiration rates at the wetland stand (Clark et al., 1999, 2004; Sun et al., 2006). The characteristics of the four stands are listed in Table 2. Forest-DNDC was applied for the four forest stands with the local climate, soil and vegetation conditions. One-year NEE fluxes measured in the four forest stands were utilized for the validation tests. Forest-DNDC simulated daily photosynthesis, plant autotrophic respiration and soil heterotrophic respiration, and further converted the 
Table 1. Physiological and phenology parameters for spruce, birch, slash pine and cypress forests adopted in Forest-DNDC.

\begin{tabular}{|c|c|c|c|c|c|}
\hline Parameter & Definition & Spruce & Birch & $\begin{array}{l}\text { Slash } \\
\text { pine }\end{array}$ & Cypress \\
\hline LeafGeo & Leaf geometry index & 1 & 2 & 1 & 1 \\
\hline AmaxA & Coefficient for Amax calculation, $\mathrm{n}$ mole $\mathrm{CO}_{2} / \mathrm{g} / \mathrm{s}$ & 9.3 & -46 & 12 & 0.1 \\
\hline AmaxB & Coefficient for Amax calculation, slope & 21.5 & 71.9 & 25 & 18 \\
\hline HalfSat & Half saturation light intensity, u mole $/ \mathrm{m} 2 / \mathrm{s}$ & 200 & 200 & 200 & 200 \\
\hline $\mathrm{k}$ & Light attenuation constant & 0.5 & 0.58 & 0.5 & 0.5 \\
\hline PsnTMin & Minimum daytime temperature for Dtemp calculation, degree $\mathrm{C}$ & -4.0 & 4.0 & 15.0 & 2 \\
\hline PsnTOpt & Optimum daytime temperature for Dtemp calculation, degree $\mathrm{C}$ & 24.0 & 24.0 & 24.0 & 24.0 \\
\hline PsnTMax & Maximum daytime temperature for Dtemp calculation, degree $\mathrm{C}$ & 45.0 & 45.0 & 45.0 & 45.0 \\
\hline DVPD1 & Coefficient A for DVPD as a function of VPD & 0.05 & 0.05 & 0.05 & 0.05 \\
\hline DVPD2 & Coefficient B for DVPD as a function of VPD & 2.0 & 2.0 & 2.0 & 2.0 \\
\hline RespQ10 & Effect of temperature on respiration & 2.0 & 2.0 & 2.0 & 2.0 \\
\hline RootMRespFrc & Ratio of fine root maintenance respiration to biomass production & 1.0 & 1.0 & 1.0 & 0.99 \\
\hline WoodMRFrc & Wood maintenance respiration as a fraction of gross Psn & 0.07 & 0.07 & 1.0 & 0.1 \\
\hline GRespFrac & Growth respiration as fraction of allocation & 0.25 & 0.25 & 0.25 & 0.17 \\
\hline FolReten & Leaf retening time, years & 4.0 & 1.0 & 1.5 & 1 \\
\hline SLWmax & Maximum specific leaf weight, $\mathrm{g}$ dry matter/m2 leaf & 170 & 100 & 280 & 200 \\
\hline GDDFolStart & GDD for leaf to start growth & 250 & 100 & 100 & 600 \\
\hline GDDFolEnd & GDD to complete foliage production, degree $\mathrm{C}$ & 1100 & 900 & 900 & 1900 \\
\hline SenescStart & Julian day to start leaf senescence & 270 & 260 & 250 & 280 \\
\hline FolNCon & Leaf $\mathrm{N}$ concentration by weight & 1.2 & 2.2 & 1.3 & 1.3 \\
\hline FolNRetrans & Fraction of leaf $\mathrm{N}$ retranslocated & 0.5 & 0.5 & 0.5 & 0.5 \\
\hline FolCNR & Leaf $\mathrm{C} / \mathrm{N}$ ratio & 37.0 & 21.0 & 35.0 & 35.0 \\
\hline BaseFolRespFrac & Dark respiration as fraction of Amax & 0.075 & 0.1 & 0.075 & 0.45 \\
\hline AmaxFrac & Daily Amax as fraction of instantaneous Amax & 0.76 & 0.76 & 0.76 & 0.75 \\
\hline PsnTOpt & Optimum temperature for photosynthesis, degree $\mathrm{C}$ & 24.0 & 24.0 & 24.0 & 24.0 \\
\hline PlantCReserveFrac & Fraction of available $\mathrm{C}$ for plant reserve & 0.75 & 0.75 & 0.75 & 0.75 \\
\hline WoodCNR & Wood $\mathrm{C} / \mathrm{N}$ ratio & 200 & 180 & 200 & 200 \\
\hline WUEConst & Water use efficiency constant & 13.9 & 13.9 & 13.9 & 13.9 \\
\hline SLWdel & Specific leaf weight, $\mathrm{g}$ dry matter/(m2 leaf $* \mathrm{~g}$ foliage mass $)$ & 0.0 & 0.2 & 0.0 & 0.0 \\
\hline FolRelGrowMax & Maximum leaf growth rate, $\% / y r$ & 0.3 & 0.95 & 0.3 & 0.3 \\
\hline MinWoodFolRatio & Minimum wood/leaf ratio & 1.25 & 1.4 & 1.25 & 1.25 \\
\hline GDDWoodStart & GDD for wood to start growth & 250 & 100 & 900 & 780 \\
\hline GDDWoodEnd & GDD for wood to end growth & 1400 & 900 & 1600 & 1730 \\
\hline
\end{tabular}

C fluxes to daily NEE fluxes for the modeled forest ecosystems. The physiological and phenology parameters of the simulated forests were adopted from Aber et al. (Aber and Federer, 1992) with minor modifications. All the forest parameters utilized in Forest-DNDC for the study are listed in Table 1.

The modeled patterns and magnitudes of NEE fluxes were basically in agreement with observations for all the four stands. On an annual basis, the measured NEE fluxes were 5830, 5011, 7400 and $840 \mathrm{~kg} \mathrm{C} / \mathrm{ha}$, and the modeled NEE fluxes were $5470,3570,6720$ and $650 \mathrm{~kg} \mathrm{C} /$ ha for the spruce in Griffin-Aberfeldy, the spruce in Tharandt, the slash pine in Grainesville and the cypress in Grainesville, respectively (Table 2). Monthly mean NEE fluxes were calculated and are shown in Fig. 3 to demonstrate the seasonality of the measured and modeled NEE fluxes. Both the measured and modeled results showed that $\mathrm{C}$ sequestration rate of the wetland forest in Florida was significantly lower than that of the three upland forests. The correlations between the measured and modeled monthly mean NEE fluxes were expressed with the R-squared values as $0.91,0.73,0.73$ and 0.57 for Tharandt, Griffin-Aberfeldy, upland Grainesville and wetland Grainesville, respectively. Except the above-described four cases tested in this study, more validation tests have been conducted for Forest-DNDC by a number of researchers worldwide (e.g., Miehle et al., 2006; Sun et al., 2006; Kesik et al., 2005; Kiese et al., 2004; Butterbach-Bahl et al., 2004; Zhang et al., 2002; Stange et al., 2000). The validation results suggested that Forest-DNDC was applicable for $\mathrm{C}$ balance studies across a wide range of forest ecosystems. In the study we applied Forest-DNDC to interpret the observed NEE fluxes from two adjacent forests with similar climate and forest structure but differing in soil conditions in Russia. 
Table 2. Characteristics of four forest stands used for validation of Forest-DNDC*.

\begin{tabular}{lllll}
\hline Stand & Griffin- Aberfeldy,UK & Tharandt, Germany & Gainesville, Florida,USA & Gainesville, Florida,USA \\
\hline Latitude & $56.6^{\circ} \mathrm{N}$ & $51^{\circ} \mathrm{N}$ & $29.6^{\circ} \mathrm{N}$ & $29.6^{\circ} \mathrm{N}$ \\
Year & 1998 & 2000 & 1996 & 1996 \\
$\begin{array}{l}\text { Age, yrs } \\
\text { Dominant species }\end{array}$ & 20 & 50 & 140 & 140 \\
$\begin{array}{l}\text { Soil } \\
\text { Land type }\end{array}$ & Spruce plantation & Spruce plantation & Slash pine & Cypress \\
$\begin{array}{l}\text { Observed annual NEE, } \\
\mathrm{kg} \mathrm{Cha}^{-1} \mathrm{yr}^{-1}\end{array}$ & Upland & 5830 & Sandy loam, acid & Sandy loam, acid \\
$\begin{array}{l}\text { Modeled acid } \\
\mathrm{kg} \mathrm{Cha}^{-1} \mathrm{yr}^{-1}\end{array}$ & Loam, acid & Upland & Wetland \\
\hline
\end{tabular}

* Measured NEE flux data from Papale et al., 2006 and Moffat et al., 2007 through the CarboeuropeIP database at http://gaia.agraria.unitus. it/database, Christian Bernho fer for Tharandt, John Moncrieff for Griffin-Aberfeldy, and Clark et al. for Gainesville sites.

\subsection{Forest-DNDC application for the Russian forests}

Long-term NEE measurements were conducted at the two Russian forests, WSF and DSF, at Fyodorovskoe from 19992004. Van der Molen and his colleagues have thoroughly analyzed the measured data and concluded that the two adjacent forests differed in $\mathrm{C}$ sequestration with WSF as a source and DSF as a sink of atmospheric $\mathrm{CO}_{2}$ ( van der Molen et al., 2007). In this study, Forest-DNDC was utilized to interpret the difference. For the model simulations, the WSF forest was set to be a 150 years old spruce forest with a 50 years old birch as the under-story; and the DSF forest was constructed with a 100 years old spruce as the upper-story with a 10 years old birch as the under-story. The WSF site had a $60-\mathrm{cm}$ organic layer containing about 200 tons $\mathrm{C} / \mathrm{ha}$, and the DSF site a $5-\mathrm{cm}$ organic layer containing 25 tons $\mathrm{C} /$ ha. Based on the field observations, we set DSF as an upland forest with the WT depth below the modeled soil depth; while we set WSF as a wetland forest with the WT depth seasonally close to the ground surface. The daily WT depth data at WSF for the period from 1999-2004 were calculated based on the WT data measured in 2004 in conjunction with the daily climate data for the six yeas. As mentioned earlier in the paper, a group of hydrological parameters have been embedded in Forest-DNDC to empirically predict the daily WT dynamics based on historical WT data. The values of the six parameters, namely initial WT depth, lowest WT depth ceasing surface outflow, lowest WT depth ceasing ground outflow, fraction of precipitation for surface inflow, intensity of surface outflow and intensity of ground outflow, can be empirically determined with a fitting-tuning method based on observed WT depth data for a specific site (Zhang et al., 2002). In this study, the WT data measured at WSF in 2004 were used to determine the parameter values. With the approach, the six parameters were endowed with the specific values as $-16 \mathrm{~cm},-15 \mathrm{~cm},-60 \mathrm{~cm}, 15,0.9$ and 0.05 , respec-

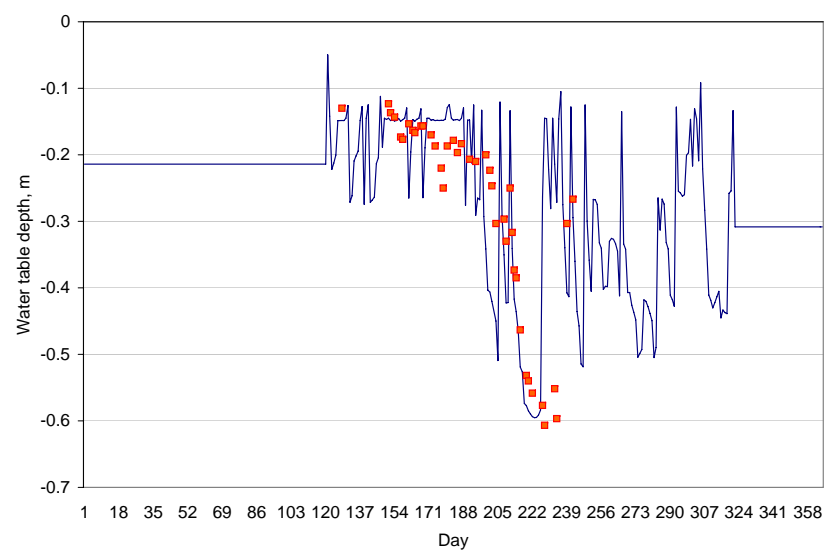

Fig. 4. Comparison of the hydrological parameters-induced water table (WT) dynamics with observed WT depth data for WSF in 2004.

tively. Equipped with the hydrological parameters, daily WT depths were calculated for the years from 1999-2004 driven by their daily climate data. Figure 4 shows the hydrological parameters-generated WT dynamics in comparison with the observed WT data for 2004. Table 3 contains the calculated WT data in comparison with the temperature and precipitation data for 1999-2004.

Driven by the actual climate, forest and soil data as well as the empirically produced WT data, Forest-DNDC simulated daily fluxes of photosynthesis, plant autotrophic respiration, soil heterotrophic respiration and NEE for WSF and DSF from 1999-2004. The modeled daily fluxes were further converted to monthly and annual fluxes for comparisons with observations. Figure 5 shows the measured and modeled monthly and annual NEE fluxes for WSF from 1999-2004. The comparison indicated that (1) the patterns and magnitudes of the modeled monthly and annually NEE fluxes were 
Table 3. Monthly average air temperature $\left(T,{ }^{\circ} \mathrm{C}\right)$, monthly sum of precipitation $(P, \mathrm{~mm})$ and modeled monthly average water table depth ( $W$, m; negative values mean below ground) for the wet spruce forest (WSF) in Fyodorovskoe, Tver, Russia from 1999-2004.

\begin{tabular}{lllllllllllll}
\hline & Jan & Feb & Mar & Apr & May & Jun & Jul & Aug & Sep & Oct & Nov & Dec \\
\hline$T_{1999}$ & -6.0 & -9.7 & -0.8 & 9.2 & 7.9 & 20.9 & 20.3 & 15.0 & 11.5 & 5.0 & -3.7 & -2.9 \\
$T_{2000}$ & -7.2 & -3.5 & -1.7 & 9.4 & 10.1 & 14.2 & 16.8 & 15.2 & 9.2 & 6.8 & 0.5 & -3.1 \\
$T_{2001}$ & -4.8 & -8.4 & -3.2 & 9.3 & 10.4 & 14.9 & 21.5 & 15.6 & 10.8 & 5.1 & -2.4 & -12.0 \\
$T_{2002}$ & -5.9 & -2.3 & 0.8 & 6.7 & 12.4 & 15.3 & 20.7 & 17.2 & 10.3 & 0.9 & -2.5 & -12.0 \\
$T_{2003}$ & -8.3 & -8.6 & -2.3 & 3.1 & 13.1 & 12.2 & 19.3 & 14.7 & 10.0 & 3.5 & 0.2 & -3.1 \\
$T_{2004}$ & -8.4 & -7.7 & 0.1 & 4.1 & 10.1 & 13.8 & 17.4 & 17.0 & 10.9 & 4.6 & -2.5 & -3.5 \\
$P_{1999}$ & 64.3 & 55.3 & 43.3 & 16.1 & 24.4 & 22.5 & 49.9 & 122.0 & 23.0 & 107.2 & 25.4 & 89.3 \\
$P_{2000}$ & 41.3 & 59.1 & 25.0 & 69.2 & 47.4 & 95.8 & 171.4 & 85.3 & 36.3 & 28.0 & 60.1 & 54.0 \\
$P_{2001}$ & 39.8 & 59.3 & 63.3 & 26.3 & 48.0 & 52.6 & 48.3 & 67.9 & 32.0 & 69.3 & 88.9 & 35.7 \\
$P_{2002}$ & 56.5 & 82.1 & 49.9 & 8.3 & 21.3 & 87.1 & 13.4 & 3.9 & 20.3 & 93.5 & & \\
$P_{2003}$ & 49.3 & 13.3 & 22.0 & 51.0 & 66.6 & 100.7 & 140.0 & 194.0 & 25.2 & 129.0 & 54.6 & 60.1 \\
$P_{2004}$ & 85.8 & 56.8 & 42.4 & 4.0 & 65.7 & 62.0 & 77.4 & 70.7 & 49.1 & 87.7 & 58.9 & 71.8 \\
$W_{1999}$ & -0.28 & -0.26 & -0.16 & -0.20 & -0.19 & -0.15 & -0.17 & -0.19 & -0.42 & -0.26 & -0.28 & -0.20 \\
$W_{2000}$ & -0.19 & -0.19 & -0.19 & -0.18 & -0.15 & -0.17 & -0.15 & -0.16 & -0.32 & -0.49 & -0.22 & -0.22 \\
$W_{2001}$ & -0.28 & -0.28 & -0.26 & -0.15 & -0.17 & -0.17 & -0.17 & -0.21 & -0.42 & -0.37 & -0.18 & -0.15 \\
$W_{2002}$ & -0.20 & -0.20 & -0.20 & -0.19 & -0.15 & -0.17 & -0.15 & -0.40 & -0.50 & -0.25 & -0.26 & -0.21 \\
$W_{2003}$ & -0.21 & -0.21 & -0.21 & -0.21 & -0.18 & -0.17 & -0.17 & -0.22 & -0.37 & -0.23 & -0.16 & -0.21 \\
$W_{2004}$ & -0.21 & -0.21 & -0.21 & -0.20 & -0.18 & -0.16 & -0.31 & -0.38 & -0.36 & -0.30 & -0.34 & -0.31 \\
\hline
\end{tabular}

basically in agreement with observations; (2) both the measured and modeled monthly NEE fluxes showed clear seasonality with sequestering $\mathrm{C}$ in early summers and releasing $\mathrm{C}$ in autumns and winters; (3) on an annual basis, the WSF ecosystem was a source of atmospheric $\mathrm{CO}_{2}$ with the $\mathrm{C}$ sequestration rates varying between -1000 and $-6000 \mathrm{~kg} \mathrm{C} / \mathrm{ha}$ per year during the tested six years; and (4) the highest loss of $\mathrm{C}$ occurred in 2002 with the lowest precipitation in the year. In contrast to WSF, the modeled NEE data indicated that DSF was a sink of atmospheric $\mathrm{CO}_{2}$. The NEE data we collected from DSF were not as complete as that from WSF. A multi-year average NEE flux value for DSF was calculated based on all the observed datasets and reported by van der Molen et al. (2007). Based on the results from van der Molen et al. (2007), the averaged annual NEE flux was $-1440 \mathrm{~kg} \mathrm{C} / \mathrm{ha}$, which was comparable with our modeled result, $-1200 \mathrm{~kg} \mathrm{C} / \mathrm{ha}$. The modeled data further indicated that the difference in NEE between WSF and DSF resulted from two reasons, i.e., forest age and SOC content. In comparison with DSF, WSF possessed relatively older trees with lower photosynthesis and higher respiration rates. In addition, WSF had more organic $\mathrm{C}$ content in its peat soil profile that caused higher soil respiration rates.

To further test the sensitivity of wetland $\mathrm{C}$ dynamics to climate change, we re-ran Forest-DNDC for the WSF site but with varied soil hydrological scenarios. Based on the 2004-observed daily water table (WT) depths as the baseline scenario (WT0), we systematically elevated the daily WT depths by 20 and $40 \mathrm{~cm}$, and decreased the daily WT depths by 20 and $40 \mathrm{~cm}$ to create four alternative scenarios,
WT+40, WT+20, WT-20 and WT-40, respectively. ForestDNDC was run for WSF with the baseline and alternative WT scenarios for year 2004. Results from the sensitivity tests indicated that when the WT scenario shifted from the highest one (i.e., WT+40) to the lowest one (i.e., WT40) (1) the fraction of soil profile allocated in the unsaturated zone significantly increased (Fig. 6a), (2) the annual soil heterotrophic respiration rate increased from 320 to $6160 \mathrm{~kg} \mathrm{C} / \mathrm{ha}$ (Fig. 6b); and (3) the annual NEE flux increased from -1820 to $3820 \mathrm{~kg} \mathrm{C} / \mathrm{ha}$. The results suggested that variation in WT dynamics alone could significantly affect the $\mathrm{C}$ balance in wetland ecosystems mainly through altering the decomposition rate of the organic matter accumulated in the soil profile. The modeled results supported the hypothesis that the soil processes, especially the decomposition process, in wetlands could play an important role in altering the $\mathrm{C}$ dynamics in the ecosystems.

\section{Discussions}

NEE measurements have been conducted worldwide during the past decades. Most of the measurements were carried out for upland forests and showed most of the upland forests were sequestering atmospheric $\mathrm{C}$. The same measurements for wetland forests were relatively sparse probably due to the difficulties of field measurements in wetlands. However, the reported wetland forests such as the Florida cypress or the Russian spruce studied in the paper, showed to be different from the upland forests. Some of the measured wetland forests appeared to have lower capacity for 

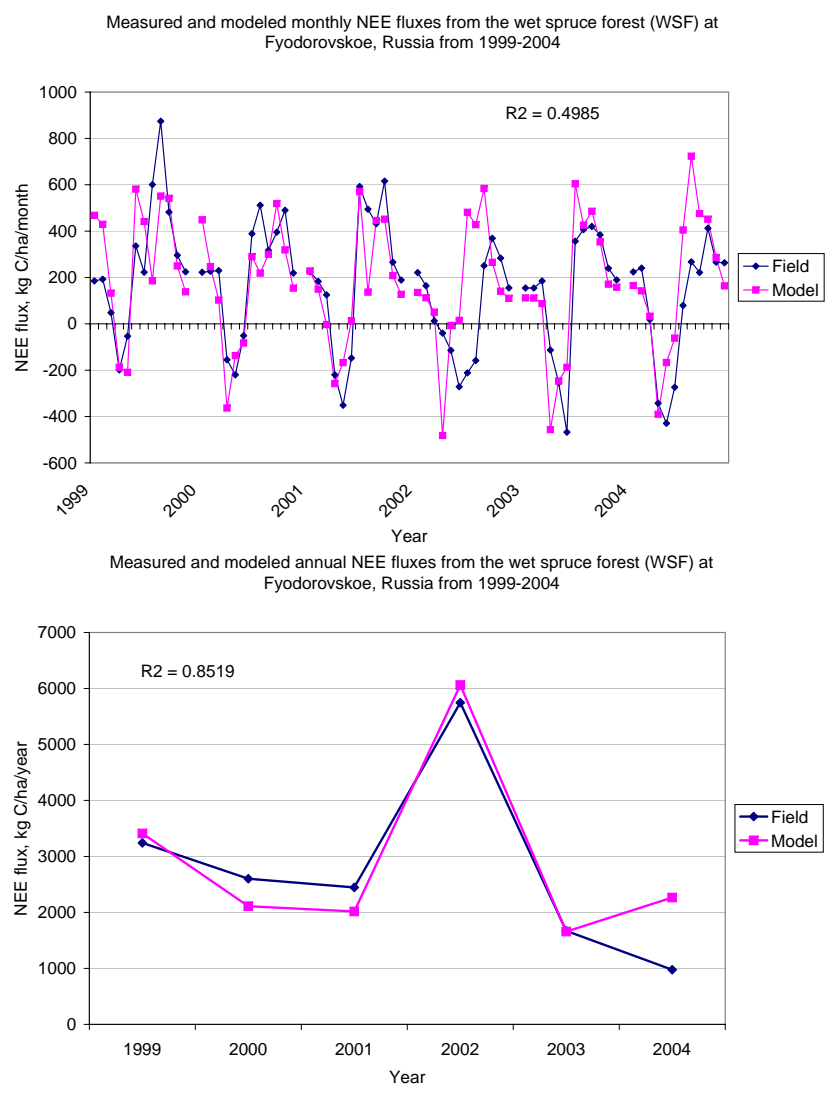

Fig. 5. Comparison between observed and Forest-DNDC modeled NEE fluxes from the wet spruce forest (WSF) in the Central Forest Reserve at Fyodorovskoe, Tver, Russia in 1999-2004 on a monthly (a) and an annual (b) basis.

sequestering $\mathrm{C}$ or be sources of atmospheric $\mathrm{CO}_{2}$. Globally, wetland soils contain a significant proportion of the terrestrial soil C (20-25\%), despite the relatively small proportion of the total land area (2-3\%) occupied. When considered on a unit area basis, upland forest soils typically have less than $3 \mathrm{~kg} \mathrm{C} \mathrm{m}^{-2}$, whereas forested wetland soils may contain from 9 to $90 \mathrm{~kg} \mathrm{C} \mathrm{m}^{-2}$ (Trettin and Jurgensen, 2003). It is apparently important to understand the feedbacks between the wetland $\mathrm{C}$ storage and global climate change. There is a hypothesis that the large amount of organic carbon stored in wetland soils could readily be released into the atmosphere if the climate becomes warmer and dryer, especially in the high latitude areas. The six-year NEE measurements at the two adjacent spruce forests at Fyodorovskoe in Russia provided a unique case for us to test the hypothesis. Based on the field observations, the two forests shared similar climate and vegetation structure but differed in soil conditions; and the measured NEE data indicated the wetland spruce forest (WSF) was a source of atmospheric $\mathrm{CO}_{2}$ while the dry spruce forest (DSF), like most upland forests, remained as a sink (van der Molen et al., 2007). In this study, we utilized a process-based model, Forest-DNDC, to interpret the ob-
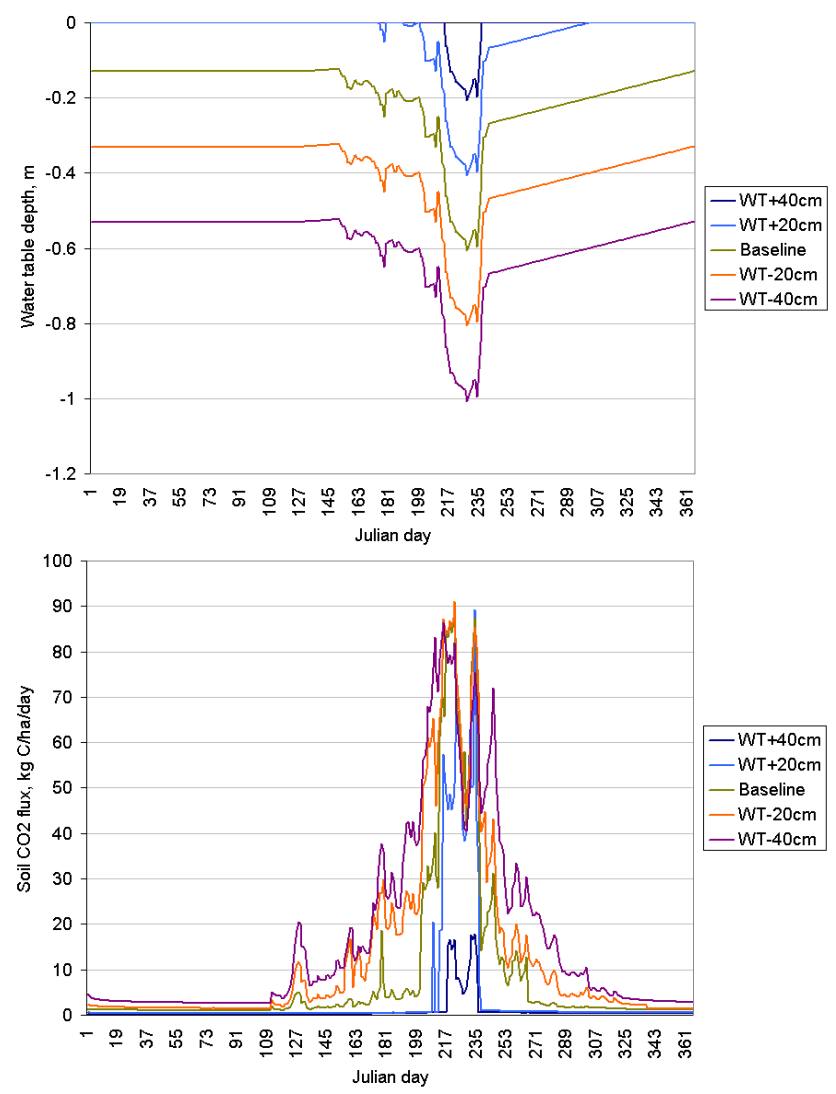

Fig. 6. A sensitivity test for the wetland spruce forest (WSF) in Fyodorovskoe, Russia. When the water table (WT) depths shifted from the high to the low scenarios, the fraction of soil profile exposed to aerobic conditions (a) and soil heterotrophic respiration rate (b) non-lineally increased.

served differences between the two forest stands. The modeled results reproduced the observations that WSF and DSF were in negative and positive $\mathrm{C}$ balances, respectively. A sensitivity test with varied WT conditions indicated that climate change could significantly affect the $\mathrm{C}$ balance in wetland forest ecosystems by altering the soil decomposition rates. A drier and warmer climate could convert wetlands from a sink to a source of atmospheric $\mathrm{CO}_{2}$. The conclusion from this modeling study could be applicable for a wide range of wetland ecosystems that have accumulated high contents of soil organic $\mathrm{C}$ during the historical period and now suffer from climate change and anthropogenic activities.

This study was also an attempt to apply a process-oriented model for climate change studies. We tested the ForestDNDC model through the study and found its advantages and weaknesses. As a biogeochemical model, Forest-DNDC possesses a relatively complete set of microorganism-driven processes such as soil redox potential dynamics, decomposition, nitrification, denitrification, fermentation etc. that enable the model to simulate the soil biochemical or geochemical processes under both aerobic and anaerobic conditions. 
In comparison with most existing $\mathrm{C}$ models, such as CENTURY, CASA or Roth-C, which were developed mainly focusing on upland ecosystems, Forest-DNDC appears more powerful to work at landscape scale that are mosaicked by wetland and upland ecosystems. However, Forest-DNDC is relatively weak in simulating forest community. The forest growth sub-model embedded in Forest-DNDC was adopted from a forest physiological model, PnET, developed by Aber and Federer (1992). PnET has well developed physiological processes but is lack of forest structure functions. To overcome the weakness, a three-layer vegetation structure was developed in Forest-DNDC to allow the users to construct a forest ecosystem by defining its upper story, under story and ground growth (e.g., sedge, moss etc.) (Zhang et al., 2002; Li et al., 2004). The upper story and under story can be defined as two different species of trees to make up a multi-species forest. For example, in this study, the modeled spruce forests in Russia were constructed with a 150 years old spruce as the upper story and a 25 years old birch as the under story. By changing the proportions of the two species, the bulk photosynthesis, respiration and other physiological parameters of the forest can be adjusted to match the corresponding observations. However, this simplification may not adequately applicable for complex forest communities. This weakness will need to be addressed in the future development of the model.

Acknowledgements. The study reported in this paper was supported by the US NASA through Northern Eurasia Earth Science Partnership Initiative (NEESPI) project "Quantifying $\mathrm{CO}_{2}$ fluxes of boreal forests in northern Eurasia through integrated analyses of in-situ flux tower, remote sensing and biogeochemical modeling" (NASA \#143192), by European Commission DG Research 5th Framework Programme, projects EUROSIBERIAN CARBONFLUX (ENV4-CT97-0491) and TCOS-Siberia (EVK2-CT-2001-00131). We appreciate the assistances provided by Christian Bernhofer, John Moncrieff, Moffat A.M. and Papale D. with their permissions to allow us to use their NEE data published at the CarboeuropeIP database (http://gaia.agraria.unitus.it/database). We thank Huiyong Sang for her decent work formatting the manuscript for submission.

Edited by: T. Laurila

\section{References}

Aber, J. D. and Federer, C. A.: A generalized, lumped-parameter model of photosynthesis, evapotranspiration and net primary production in temperate and boreal forest ecosystems, OECOLOGIA, 92, 463-474, 1992.

Aubinet, M., Grelle, A., Ibrom, A., Rannik, U., Moncrieff, J., Foken, T., Kowalski, A. S., Martin, P. H., Berbigier, P., Bernhofer, C., Clement, R., Elbers, J., Granier, A., Grunwald, T., Morgenstern, K., Pilegaard, K., Rebmann, C., Snijders, W., Valentini, R., and Vesala, T.: Estimates of the annual net carbon and water exchange of forests: The euroflux methodology, Advances in Ecological Research, 30(30), 113-175, 2000.
Butterbach-Bahl, K., Kesik, M., Miehle, P., Papen, H., and Li, C.: Quantifying the regional source strength of n-trace gases across agricultural and forest ecosystems with process based models, Plant and Soil, 260, 311-329, 2004.

Clark, K. L., Gholz, H. L., Moncrieff, J. B., Cropley, F., Loescher, H. W.: Environmental controls over net exchanges of carbon dioxide from contrasting Florida ecosystems, Ecological Applications, 9(3), 936, 1999.

Clark, K. L., Gholz, H. L., and M. S. Castro, M. S.: Carbon dynamics along a chronosequence of slash pine plantations in north Florida, Ecological Applications, 14:4. 1154-1171, 2004.

Cui, J., Li, C., Sun, G., and Trettin, C.: Linkage of mike she to wetland-dndc for carbon budgeting and anaerobic biogeochemistry simulatio, Biogeochemistry, 72, 147-167, 2005.

Dixon, R. K., Brown, S., Houghton, R., Solomon, S. C., Trexler, M. C., and Wisniewski, J.: Carbon pools and flux of global forest ecosystems, Science, 263, 185-190, 1994.

Falge, E., Baldocchi, D., Tenhunen, J., Aubinet, M., Bakwin, P., Berbigier, P., Bernhofer, C., Burba, G., Clement, R., Davis, K. J., Elbers, J. A., Goldstein, A. H., Grelle, A., Granier, A., Guomundsson, J., Hollinger, D., Kowalski, A. S., Katul, G., Law, B. E., Malhi, Y., Meyers, T., Monson, R. K., Munger, J. W. Oechel, W., Paw, K. T., Pilegaard, K., Rannik, U., Rebmann, C., Suyker, A., Valentini, R., Wilson, K., and Wofsy, S.: Seasonality of ecosystem respiration and gross primary production as derived from fluxnet measurements, Agricultural and Forest Meteorology, 113, 53-74, 2002.

Fan, S., Gloor, M., Mahlman, J., Pacala, S., Sarmiento, J., Takahashi, T., and Tans, P.: A large terrestrial carbon sink in north america implied by atmospheric and oceanic carbon dioxide data and models, Science, 282, 442-446, 1998.

Hamada, S., Ohta, T., Hiyama, T., Kuwada, T., Takahashi, A., and Maximov, T. C.: Hydrometeorological behaviour of pine and larch forests in eastern siberia, Hydrological Processes, 18, 23 39, 2004.

Hollinger, D. Y., Kelliher, F. M., Schulze, E. D., Bauer, G., Arneth, A., Byers, J. N., Hunt, J. E., McSeveny, T. M., Kobak, K. I., Milukova, I., Sogatchev, A., Tatarinov, F., Varlargin, A., Ziegler, W., and Vygodskaya, N. N.: Forest-atmosphere carbon dioxide exchange in eastern siberia, Agricultural and Forest Meteorology, 90, 291-306, 1998.

Jarvis, P. and Linder, S.: Constraints to growth of boreal forests, Nature, 405, 904-905, 2000.

Jarvis, P., Saugier, B., and Schulze, E. D.: Producitivity of boreal forests, in: Terrestrial global productivity, edited by: Roy, J., Saugier, B., and Mooney, H. A., Academic Press Inc., San Diego, CA, 211-244, 2001.

Kesik, M., Ambus, P., Baritz, R., Bruggemann, N. B., ButterbachBahl, K., Damm, M., Duyzer, J., Horvath, L., Kiese, R., Kitzler, B., Leip, A., Li, C., Pihlatie, M., Pilegaard, K., Seufert, G., Simpson, D., Skiba, U., Smiatek, G., Vesala, T., and ZechmeisterBoltenstern, S.: Inventories of $\mathrm{N}_{2} \mathrm{O}$ and $\mathrm{NO}$ emissions from european forest soils, Biogeosciences, 2, 353-375, 2005, http://www.biogeosciences.net/2/353/2005/.

Kiese, R., Li, C., Hilbert, D., Papen H., and Butterbach-Bahl, K.: Regional application of PnET-N-DNDC for estimating the $\mathrm{N}_{2} \mathrm{O}$ source strength of tropical rainforests in the Wet Tropics of Australia, Global Change Biol., 11, 128-144, 2004. 
Kobak, K. I., Turchinovich, I. Y., Kondrasheva, N. Y., Schulze, E. D., Schulze, W., Koch, H., and Vygodskaya, N. N.: Vulnerability and adaptation of the larch forest in eastern siberia to climate change, Water, Air, and Soil Pollution, 92, 119-127, 1996.

Kolle, O. and Rebmann, C.: EddySoft - Documentation of a Software Package to Aquire and Process Eddy Covariance Data, Max-Planck-Institut fur Biogeochemie, Jena, Technical Report, 10, 85, 2007.

Li, C., Aber, J. D., Stange, F., Butterbach-Bahl, K., and Papen, H.: A process-oriented model of $\mathrm{N} 2 \mathrm{O}$ and $\mathrm{NO}$ emissions from forest soils: 1. Model developement, J. Geophys. Res.-Atmos., 105, 4369-4384, 2000.

Li, C., Cui, J., Sun, G., and Trettin, C. C.: Modeling impacts of management on carbon sequestration and trace gas emissions in forested wetland ecosystems, Environmental Management, 33, 176-186, 2004.

Li, C.: Quantifying greenhouse gas emissions from soils: Scientific basis and modeling approach, Soil Science and Plant Nutrition, 53, 344-352, 2007.

Lloyd, J., Shibistova, O., Zolotoukhine, D., Kolle, O., Arneth, A., Wirth, C., Styles, J. M., Tchebakova, N., and Schulze, E. D.: Seasonal and annual variations in the photosynthetic productivity and carbon balance of a central siberian pine forest, Tellus Series B-Chemical and Physical Meteorology, 54B, 590-610, 2002.

Melillo, J. M., Mcguire, A. D., Kicklighter, D. W., Moore, B., Vorosmarty, C. J., and Schloss, A. L.: Global climate-change and terrestrial net primary production, Nature, 363, 234-240, 1993.

Miehle, P., S.J. Livesley, P.M. Feikema, C. Li, and S.K. Arndt. Assessing productivity and carbon sequestration capacity of Eucalyptus globulus plantations using the process model ForestDNDC: Calibration and validation. Ecological Modelling 192, 83-94, 2006.

Milyukova, I. M., Kolle, O., Varlagin, A. V., Vygodskaya, N. N., Schulze, E. D., and Lloyd, J.: Carbon balance of a southern taiga spruce stand in european russia, Tellus Series B-Chemical and Physical Meteorology, 54, 429-442, 2002.

Moffat, A. M., Papale, D., Reichstein, M., Hollinger, D. Y., Richardson, A. D., Barr, A. G., Beckstein, C., Braswell, B. H., Churkina, G., Desai, A. R., Falge, E., Gove, J. H., Heimann, M., Hui, D., Jarvis, A. J., Kattge, J., Noormets, A., and Stauch, V. J.: Comprehensive comparison of gap-filling techniques for eddy covariance net carbon fluxes, Agr. Forest Meteorol., 147, 209-232, 2007.

Myneni, R. B., Dong, J., Tucker, C. J., Kaufmann, R. K., Kauppi, P. E., Liski, J., Zhou, L., Alexeyev, V., and Hughes, M. K.: A large carbon sink in the woody biomass of northern forests, Proceedings of the National Academy of Sciences of the United States of America, 98, 14 784-14 789, 2001.

Ohta, T., Hiyama, T., Tanaka, H., Kuwada, T., Maximov, T. C., Ohata, T., and Fukushima, Y.: Seasonal variation in the energy and water exchanges above and below a larch forest in eastern siberia, Hydrological Processes, 15, 1459-1476, 2001.

Papale, D., Reichstein, M., Aubinet, M., Canfora, E., Bernhofer, C., Longdoz, B., Kutsch, W., Rambal, S., Valentini, R., Vesala, T., Yakir, D.: Towards a standardized processing of Net Ecosystem Exchange measured with eddy covariance technique: algorithms and uncertainty estimation, Biogeosciences, 3, 571-583, 2006, http://www.biogeosciences.net/3/571/2006/.

Reichstein, M., Falge, E., Baldocchi, D., Papale, D., Aubinet,
M., Berbigier, P., Bernhofer, C., Buchmann, N., Gilmanov, T., Granier, A., Grunwald, T., Havr'ankov'a, K., Ilvesniemi, H., Janous, D., Knohl, A., Laurila, T., Lohila, A., Loustau, D., Matteucci, G., Meyers, T., Miglietta, F., Ourcival, J.-M., Pumpanen, J., Rambal, S., Rotenberg, E., Sanz, M., Tenhunen, J., Seufert, G., Vaccari, F., Vesala, T., Yakir, D., and Valentini, R.: On the separation of net ecosystem exchange into assimilation and ecosystem respiration: review and improved algorithm, Global Change Biol., 11, 1424-1439, 2005.

Roeser, C., Montagnani, L., Schulze, E. D., Mollicone, D., Kolle, O., Meroni, M., Papale, D., Marchesini, L. B., Federici, S., and Valentini, R.: Net $\mathrm{CO}_{2}$ exchange rates in three different successional stages of the "Dark taiga" Of central siberia, Tellus Series B-Chemical and Physical Meteorology, 54 B, 642-654, 2002.

Schimel, D. S., House, J. I., Hibbard, K. A., Bousquet, P., Ciais, P., Peylin, P., Braswell, B. H., Apps, M. J., Baker, D., Bondeau, A., Canadell, J., Churkina, G., Cramer, W., Denning, A. S., Field, C. B., Friedlingstein, P., Goodale, C., Heimann, M., Houghton, R. A., Melillo, J. M., Moore, B., Murdiyarso, D., Noble, I., Pacala, S. W., Prentice, I. C., Raupach, M. R., Rayner, P. J., Scholes, R. J., Steffen, W. L., and Wirth, C.: Recent patterns and mechanisms of carbon exchange by terrestrial ecosystems, Nature, 414 169-172, 2001.

Schulze, E. D., Lloyd, J., Kelliher, F. M., Wirth, C., Rebmann, C., Luhker, B., Mund, M., Knohl, A., Milyukova, I. M., Schulze, W., Ziegler, W., Varlagin, A. B., Sogachev, A. F., Valentini, R., Dore, S., Grigoriev, S., Kolle, O., Panfyorov, M. I., Tchebakova, N., and Vygodskaya, N. N.: Productivity of forests in the eurosiberian boreal region and their potential to act as a carbon sink a synthesis, Global Change Biology, 5, 703-722, 1999.

Shvidenko, A. and Nilsson, S.: Dynamics of russian forests and the carbon budget in 1961-1998: An assessment based on long-term forest inventory data, Climatic Change, 55, 5-37, 2002.

Stange, F., Butterbach-Bahl, K., Papen, H., ZechmeisterBoltenstern, S., Li, C. S., and Aber, J.: A process-oriented model of $\mathrm{n} 2 \mathrm{o}$ and no emissions from forest soils 2 . Sensitivity analysis and validation, J. Geophys. Res.-Atmos., 105, 4385-4398, 2000

Stange, F., Butterbach-Bahl, K., Papen, H., ZechmeisterBoltenstern, S., Li, C., Aber, J.: A process-oriented model of $\mathrm{N} 2 \mathrm{O}$ and $\mathrm{NO}$ emission from forest soils 2, Sensitivity analysis and validation, J. Geophys. Res., 105 , 4 , 4385-4398, 2000.

Sun, G., Li, C., Trettin, C., Lu, J., and McNulty, S. G.: Simulating the Biogeochemical Cycles in Cypress Wetland-Pine Upland Ecosystems at a Landscape Scale with the Wetland-DNDC Model. In Proceedings of the International Conference on Hydrology and Management of Forested Wetlands. April 8-12, 2006. New Bern, NC, 261-270, 2006.

Trettin, C. C. and Jurgensen, M. F.: Carbon cycling in wetland forest soils. Pg. 311-331, In: J. Kimble, R. Birdsie, R. Lal. Carbon Sequestration in US Forests, Lewis Publisher. Boca Raton, FL. 2003.

Vygodskaya, N., Abrazhko, V., Varlagin, A., Kurbatova, Y., Sidorov, K., Milukova, I., Sogachev, A., Sogacheva, L., Shaposhnikov, E., Nepomnyashii, G., and Abrazhko, M.: Long-term dynamics of soil moisture and drying of spruce trees in spruce forests of the southern taiga, Lesovedenie, 1, 3-22, 2004a.

Vygodskaya, N. N., Schulze, E. D., Tchebakova, N. M., Karpachevskii, L. O., Kozlov, D., Sidorov, K. N., Panfyorov, M. I., Abrazko, M. A., Shaposhnikov, E. S., Solnzeva, O. N., 
Minaeva, T. Y., Jeltuchin, A. S., Wirth, C., and Pugachevskii, A. V.: Climatic control of stand thinning in unmanaged spruce forests of the southern taiga in european russia, Tellus Series BChemical and Physical Meteorology, 54, 443-461, 2002.

Vygodskaya, N. N., Oltchev, A. V., Kurbatova, J. A., and Varlargin, A.: Gross primary production (gpp) of unmanaged over-mature spruce forests at southern european taiga: Eddy covariance measurements and modeling approach, in: Modeling forest production, scientific tools - data needs and sources, validation and application, edited by: Hasenauer, H., and Makela, A., 421-430, 2004b.
Zhang, Y., Li, C. S., Trettin, C. C., Li, H., and Sun, G.: An integrated model of soil, hydrology, and vegetation for carbon dynamics in wetland ecosystems, Global Biogeochem. Cy., 16, $1061,2002$. 